\title{
Restoring nutrient circularity in a nutrient-saturated area in Germany requires systemic change
}

\author{
Bernou Zoë van der Wiel (1D · Jan Weijma · Corina Everarda van Middelaar • \\ Matthias Kleinke $\cdot$ Cees Jan Nico Buisman · Florian Wichern
}

Received: 19 January 2021 / Accepted: 15 September 2021/Published online: 6 October 2021

(C) The Author(s) 2021

\begin{abstract}
Regions with intensive agriculture often encounter environmental problems caused by nutrient excess of agro-food-waste systems that have become increasingly linear over previous decades. In this study, nitrogen $(\mathrm{N})$, phosphorus $(\mathrm{P})$, potassium (K) and carbon (C) flows in the whole agro-foodwaste system of district Cleves in Germany were quantified simultaneously using substance flow analysis. Moreover, nutrient use inefficiency hotspots were identified to establish options to improve nutrient selfsufficiency as a first step towards nutrient circularity.
\end{abstract}

Supplementary Information The online version contains supplementary material available at https://doi.org/10.1007/ s10705-021-10172-3.

B. Z. van der Wiel $(\bowtie) \cdot$ M. Kleinke $\cdot$ F. Wichern $(\bowtie)$ Soil Science and Plant Nutrition, Institute of Biogenic Resources in Sustainable Food Systems-From Farm to Function, Rhine-Waal University of Applied Sciences, Marie-Curie-Str. 1, 47533 Kleve, Germany e-mail: bernouzoe.vanderwiel@hochschule-rhein-waal.de

F. Wichern

e-mail: florian.wichern@hochschule-rhein-waal.de

B. Z. van der Wiel · J. Weijma - C. J. N. Buisman Department of Environmental Technology, Wageningen University \& Research, P.O. Box 17, 6700 AA Wageningen, The Netherlands

C. E. van Middelaar

Animal Production Systems Group, Wageningen

University \& Research, P.O. Box 338,

$6700 \mathrm{AH}$ Wageningen, The Netherlands
Data on mass flows and nutrient contents was acquired for the year 2016 from stakeholders, statistical databases, literature and modelling. Organic $\mathrm{C}$ was included for flows with potential as organic fertilizer. Results show that animal production drives the nutrient flows in the export-oriented district, with feed import, manure application and losses from housing and manure storage accounting for 40,45 and $60 \%$ of all $\mathrm{N}, \mathrm{P}$ and $\mathrm{K}$ flows, respectively. In particular agriculture is responsible for $\mathrm{N}$ losses, with $150 \mathrm{~kg} \mathrm{~N}$ lost $\mathrm{ha}^{-1}$ agricultural land. Crop production surplus and with that soil accumulation of $\mathrm{P}$ and $\mathrm{K}$ are $515 \mathrm{t}$ and $4100 \mathrm{t}$ respectively. Stoichiometry of N:P:K:C in the different organic materials does not allow direct application and meeting crop requirements without exceeding demand of especially P. Processing of biomass is therefore required. Based on mass, especially manure holds potential for processing into biobased fertilizers. To improve nutrient cycling and soil $\mathrm{C}$ conservation, being an important element for a sustainable agricultural sector, local balances between crop and animal production need to be considered.

Keywords Agro-food-waste system - Circularity · Substance flow analysis (SFA) · Local · Nutrients · Carbon 


\section{Introduction}

Currently, food production in Europe and other areas of intensive agriculture depends heavily on external inputs of inorganic nitrogen $(\mathrm{N})$, phosphorus $(\mathrm{P})$ and also potassium (K) fertilizers (Bellarby et al. 2018; Kuokkanen et al. 2017). Furthermore, due to specialization of agriculture, spatial separation of production and consumption of feed crops, and globalization of agricultural trade beginning towards the end of the nineteenth century, local nutrient cycles between animal and crop production became decoupled (Le Noë et al. 2018; Theobald et al. 2016). Despite the abundant availability of $\mathrm{N}_{2}$ in the atmosphere, it is not bioavailable for most crops and needs to be transformed into reactive $\mathrm{N}$ forms. The synthesis of $\mathrm{N}$ fertilizer from $\mathrm{N}_{2}$, however, is energy intensive, requiring high inputs of fossil fuel (Maurer et al. 2002). P, on the other hand, is a finite resource and phosphate rock reserves are mainly concentrated in a small number of countries (Cordell and White 2015). In combination with the rising value due to high demand from a growing global human population, this may cause geopolitical tension (Cordell and White 2015). Furthermore, some areas in the world are dependent on diminishing reserves of $\mathrm{K}$ (Bellarby et al. 2018; Santos et al. 2017; Sipert et al. 2020) and in light of climatic extremes, K's role in plant and soil functions, such as for the soil's water holding capacity and plant drought stress alleviation, might become more important. Other regions of the world have insufficient access to inorganic fertilizers, which limits production of crops and impairs food security (Van Ittersum et al. 2016).

In current agro-food-waste systems nutrient losses occur throughout the chain, from losses due to overfertilization, to losses of nutrients through discharge of sewage effluent (Treadwell et al. 2018; Wendland et al. 2020). In Germany over the last years on average $227 \mathrm{~kg} \mathrm{~N}^{-1}$ were applied in primary production, with an annual crop removal of $149 \mathrm{~kg} \mathrm{~N} \mathrm{ha}^{-1}$ this resulted in an average budget surplus of $77 \mathrm{~kg} \mathrm{~N} \mathrm{ha}^{-1}$ (Häußermann et al. 2020). Some of this excess $\mathrm{N}$ is lost and causes multiple environmental issues such as eutrophication of terrestrial and aquatic ecosystems, which in turn can lead to a loss of biodiversity (De Vries et al. 2013; Van Grinsven et al. 2010). Above mentioned issues show the need to improve nutrient cycling, to become less dependent on fossil resources and to contribute to reduced emissions. Excess application of one plant nutrient, for example, can result in imbalanced nutrient availability, reducing the nutrient use efficiency because of a defined stoichiometric essential nutrient demand of plants, with the lowest nutrient defining the production level, leaving nutrients applied in excess unused. However, as crops vary in their nutrient demand for the essential macro nutrients $\mathrm{N}, \mathrm{P}$ and $\mathrm{K}$, the elemental stoichiometry of fertilizers varies. Consequently, local nutrient recycling requires to link the N:P:K stoichiometry in biomasses that are locally available as nutrient sources with the demand of crops based on their stoichiometry. As a first step towards improvement, therefore, N, P and K flows and demands need to be assessed simultaneously.

Besides the essential plant macronutrients N, P and $\mathrm{K}$, also organic carbon $(\mathrm{C})$ is vital for crop cultivation, as it contributes to formation of soil organic matter (SOM) (Kallenbach et al. 2016). SOM plays a crucial role in maintaining key soil functions that serve soil fertility, as it enhances water holding capacity, water infiltration, nutrient retention and nutrient provision to plants roots (Lal 2004; Paul 2016). However, intensive agricultural activities, in particular frequent soil disturbance like tillage, increases the conversion of SOM by soil microorganisms to carbon dioxide $\left(\mathrm{CO}_{2}\right)$ (Kallenbach et al. 2016; Miltner et al. 2012; Steinmann et al. 2016). Increased organic matter input and reduced soil disturbance along with optimal nutrient availability for plants and soil facilitates sequestration of $\mathrm{C}$ in the soil after uptake by plants. In contrast, an unbalanced nutrient stoichiometry, e.g. from excess $\mathrm{N}$ application, results in less efficient organic $\mathrm{C}$ use by plants as well as larger organic $\mathrm{C}$ losses caused by lower microbial $\mathrm{C}$ use efficiency (Joergensen and Wichern 2018; Verger et al. 2018). This paper includes $\mathrm{C}$ as it is present in waste streams (e.g. manure) and relevant for both plant growth as well as SOM formation and thus crucial in climate change mitigation and adaptation. In addition to quantifying the specific ratios of $\mathrm{N}, \mathrm{P}$ and $\mathrm{K}$ in biomass, and the crop specific demand for these nutrients simultaneously, organic $\mathrm{C}$ needs to be included for the relevant biomasses to avoid disregarding organic matter provision when processing biomass into bio-based fertilizers and assessing the full potential of recycling biomasses (Moinard et al. 2021). 
An indispensable first step to improve nutrient cycling in a geographic area is to assess the current nutrient flows on system level (Chowdhury et al. 2014; Mehta et al. 2016; van der Wiel et al. 2020). Substance Flow Analyses (SFA) quantify the stocks and flows of substances of choice throughout a system predefined in space and time. It can thereby identify hotspots of inefficient nutrient use where interventions may have a high impact (Brunner and Rechberger 2016). SFA's for the nutrients $\mathrm{N}, \mathrm{P}$ and $\mathrm{K}$ have been conducted on various scales from global (Van Vuuren et al. 2010) to field level (Bučiene et al. 2003). A wide geographic scale, such as for a country, fails to capture local nuances of nutrient surplus within a study area and therefore the potential for optimizing redistribution locally (Klinglmair et al. 2015; Senthilkumar et al. 2012). A narrow scale, like the farm or field scale, does not include all supply and demand as not all subsystems which are part of the agro-food-waste system are included. When striving for closing nutrient cycles a local scale, to keep transport of biomass to a minimum, is therefore vital to capture local circumstances and thereafter adjust nutrient management accordingly (van der Wiel et al. 2020). Various SFA studies on local scales of areas with differing levels of nutrient surplus, have been performed (Chowdhury et al. 2018; Coppens et al. 2016; Theobald et al. 2016). However, currently no study captures the flows of the main macronutrients for crop growth or considers the stoichiometric balance between $\mathrm{N}, \mathrm{P}, \mathrm{K}$ and $\mathrm{C}$ while simultaneously covering the whole agro-food-waste system (van der Wiel et al. 2020).

The objective of the present study was to quantify the N, P and K flows throughout the agro-food-waste system of a nutrient-saturated area. This paper hypothesized that a nutrient-saturated area requires systemic change to restore nutrient circularity and identifies options to improve the nutrient self-sufficiency of the system as a first step towards nutrient circularity within the district. Nutrient self-sufficiency, the extent to which a system provides its own input, contributes to circularity as it reduces resource import and nutrient losses, in particular in nutrient surplus areas (Jurgilevich et al. 2016). For flows of biomass potentially available as fertilizers or soil amendments, the analysis was extended to include $\mathrm{C}$, which is relevant for SOM maintenance.

\section{Materials and methods}

Description of study area

The district Cleves in the German state of North Rhine-Westphalia is characterized by intensive agriculture with high nutrient inputs and lies close to several urban centres. These characteristics and the location, bordering other areas with intensive agriculture and high nutrient input, makes it a suitable model area for this study. District Cleves (German: Kreis Kleve) covers $1233 \mathrm{~km}^{2}$ based on the administrative border, and is located in the Lower Rhine region of the federal state North Rhine-Westphalia (NRW), Germany. In the west and north, Cleves is neighbouring the Netherlands and in the east and south it is bordered by three other German districts. With an average annual population growth since 2007 of 156 inhabitants $(0.5 \%)$, the population of the district was 310,329 in the investigation year 2016. The total farmland area in the same year covered $708 \mathrm{~km}^{2}$. This corresponds to $57 \%$ of the total area in the district, placing it amongst the one-third most rural districts in the state (NRW, 2018; Regionalstatistik, 2021). Of the farmland 49,585 ha was arable land and 21,254 ha was grassland in 2016 (NRW 2018). In the reference year (2016) $5 \%$ of the working population was employed in agriculture.

Cleves is, as are the surrounding districts, largely rural. It contains small ( $\leq 29,999$ inhabitants) urban centres and is in the vicinity (circa $100 \mathrm{~km}$ ) of several larger urban areas ( $\geq 100,000$ inhabitants), such as the Ruhr region, the Rhineland (Aachen, Cologne, Düsseldorf), and the Arnhem/Nijmegen and Randstad regions in the Netherlands. The district is characterized by intensive animal production (in particular cattle (101,713 large livestock units (LLU)), pigs (41,141 LLU) and poultry (6,681 LLU)) and production of cash crops (i.e. potatoes, sugar beet, cereals and corn), vegetables and ornamentals (NRW 2018). These activities are associated with large inputs of feed and fertilizer into the animal and crop production subsystems. Livestock density (expressed in large livestock units (LLU)) per ha agricultural area is 2.2, well above the average animal density in NRW of 1.6 (NRW 2018). As a result of prolonged surplus $\mathrm{N}$ fertilization, some groundwater bodies in the Cleves district exceed the threshold of $50 \mathrm{mg}$ nitrate litre $^{-1}$ as 
set in the European Water Framework Directive 2000/60/EC (Wendland et al. 2020).

Moreover, the vicinity to the Netherlands makes Cleves an export destination for organic fertilizers (e.g. mushroom substrate and manure) from that country. Cleves' nutrient flows are therefore strongly related to those of the Netherlands, as in 2014 it supplied $58 \%$ of the imported organic fertilizers, while the rest came from other districts in NRW and from one other federal state (Lower Saxony) (NRW, 2014).

The district of Cleves harbours several food and feed processing industries (e.g. ForFarmers (feed processing), Katjes (candy manufacturing), Pfeiffer $\&$ Langen (sugar production), etc.). These processing industries utilize raw materials from outside the district and locally produced vegetal and animal products. Besides part of their products, also nutrient rich by-products generated during processing remain in the region which add to the nutrient flows in the district.

Substance flow analysis model description

A SFA model was developed for the flows of N, P, K and $\mathrm{C}$ in the agro-food-waste system of the Cleves district, based on the conceptual design by van der Wiel et al. (2020) using STAN 2.6 modelling software (Cencic and Rechberger 2008). The geographic boundary was defined by the administrative border. For the quantification of flows the year 2016 was chosen as reference, as it was the most recent year with the highest data availability. In the model, the agrofood-waste system was divided into 5 subsystems: (1) crop production, (2) animal production, (3) food and feed processing industry, (4) consumption and (5) waste management (Fig. 1). A detailed description of each subsystem can be found in Supplementary Material A.

\section{Computation of nutrient flows}

The flows of nutrients imported into the region, the nutrient flows between the subsystems in the district, and the flows of nutrients exported out of the district were identified through stakeholder and literature consultation. To compute the nutrient flows, firstly information on the biomass flows was acquired, thereafter the nutrient concentrations of the biomasses was compiled (Brunner and Rechberger 2016). In some cases, especially for the flows related to agriculture, the flows were directly acquired as nutrient flows. Face-to-face interviews and e-mail correspondences were undertaken initially to consult different stakeholders and experts within the system. Data was thereafter acquired from statistical databases freely accessible at statistical websites (e.g. Destatis), personal consultation, literature and modelling. For flows where no data was available for 2016, data from the next previous or following year was used and extrapolated to 2016. For the crop production subsystem also the nutrient stock change (e.g. accumulation in soil) over the reference year was quantified (see below). For the other subsystems it was assumed that no stock changes occurred (Figs. 1, 2 and 3).

For the computation of nutrient flows the following first equation was applied:

$$
\begin{aligned}
& \text { Nutrient flow }\left(\mathrm{kg}_{\mathrm{NPKC}} / \text { year }\right) \\
& =\text { mass of biomass flow }\left(\mathrm{kg}_{\text {biomass }} / \text { year }\right) \\
& \quad * \text { nutrient concentration of the biomass } \\
& \quad\left(\mathrm{kg}_{\mathrm{NPKC}} / \mathrm{kg}_{\text {biomass }}\right)
\end{aligned}
$$

Biomass flows were expressed in metric ton (t) fresh mass or in $\mathrm{t}$ dry matter, based on data availability. The corresponding nutrient content was selected accordingly. Where no corresponding nutrient content was available, the mass flow was converted based on the dry matter content of the biomass.

The $\mathrm{N}$ losses occurring during the cultivation of crops through nitrate $\left(\mathrm{NO}_{3}{ }^{-}\right)$leaching and ammonia $\left(\mathrm{NH}_{3}\right)$, nitrous oxide $\left(\mathrm{N}_{2} \mathrm{O}\right)$ and dinitrogen $\left(\mathrm{N}_{2}\right)$ gaseous emissions, were lumped and modelled by assuming the principle of mass conservation (all inputs-all outputs). The inputs covered inorganic fertilizers and different organic fertilizers, and the output were harvested crops. This principle was used as $\mathrm{N}$ does not accumulate in soils in the district (Steinmann et al. 2016). In contrast to N, for P and K losses and soil accumulation were assumed based on literature (Kayser et al., 2012; Schoumans 2015). These losses are assumed as the local intensive agricultural activities over time, after soil $\mathrm{P}$ and $\mathrm{K}$ accumulation and saturation, can lead to leaching to groundwater (Eder 2001; Fischer et al. 2017; Kayser and Isselstein 2005).

To compute $\mathrm{P}$ and $\mathrm{K}$ soil stock changes in case of crop production, this second equation was applied: 


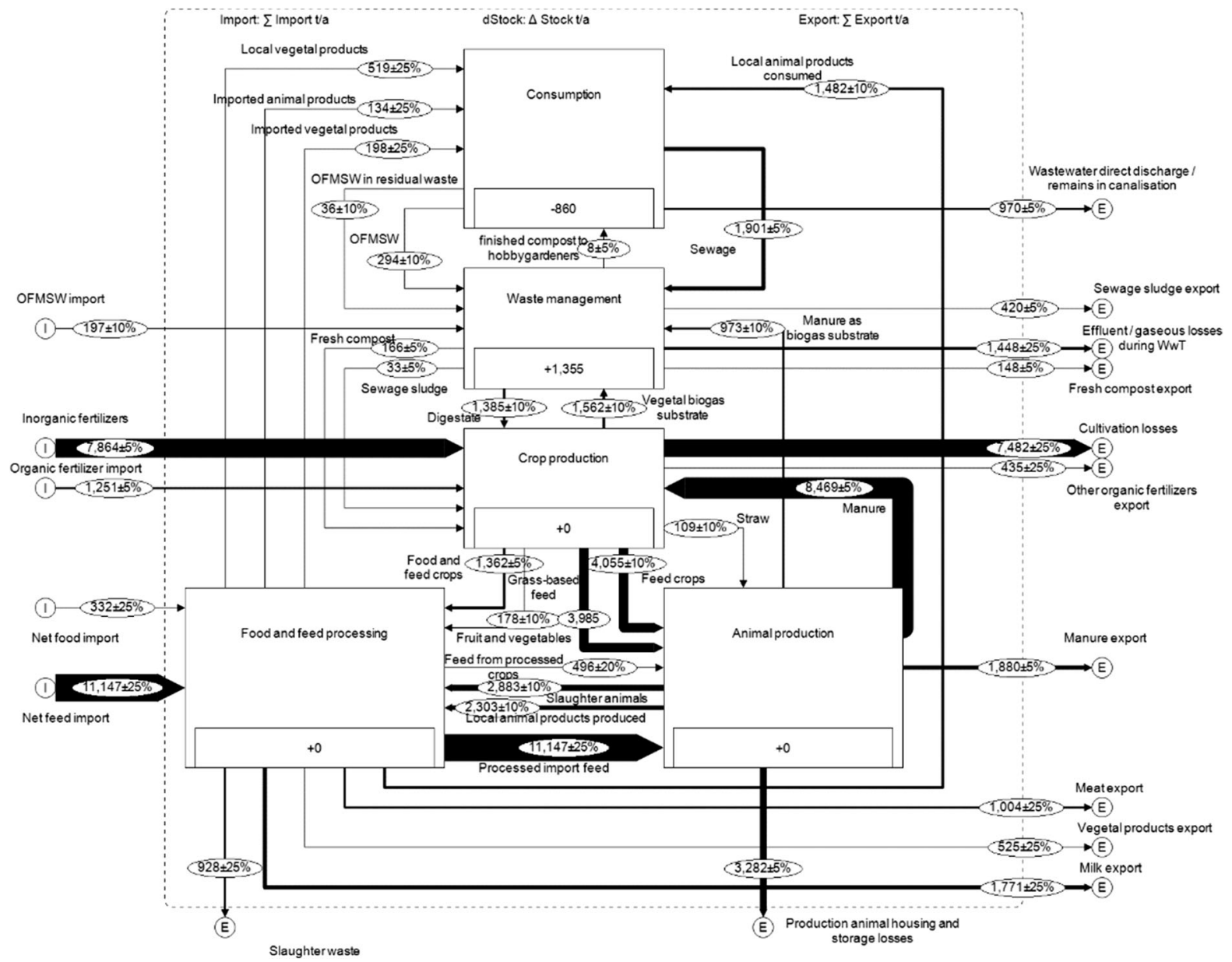

Fig. 1 Nitrogen SFA with flows in ton year $^{-1} . \mathrm{I}=$ import $\mathrm{E}=$ export. WwT $=$ wastewater treatment

Total inputs - total outputs

- leaching rate $\mathrm{ha}^{-1}$ agricultural land

$*$ agricultural land $=$ annual stock change

(all in $\mathrm{kg}_{\mathrm{NPKC}} /$ year)

When no data for a flow was available, neither through expert consultation, databases, nor from literature, the flow was computed based on the principle of mass conservation (Brunner and Rechberger 2016).

A range of flows such as minor animal products (e.g. wool) and crop seeds were regarded as negligible based on literature and were therefore excluded (Häußermann et al. 2020; Wironen et al. 2018). Moreover, atmospheric deposition of N, P and $\mathrm{K}$ was excluded due to the difficulty in attaining district specific data as it spatially varies depending on local management practices (Wendland et al. 2020). However, atmospheric $\mathrm{N}$ deposition in Germany, which was on average $14 \mathrm{~kg} \mathrm{~N} \mathrm{ha}^{-1} \mathrm{a}^{-1}$ (Häußermann et al. 2020) but in the state North Rhine-Westphalia as high as $30 \mathrm{~kg} \mathrm{~N}$ ha $^{-1} \mathrm{a}^{1}{ }^{1}$ (Wendland et al. 2020), needs to be considered when assessing means of reducing $\mathrm{N}$ loads to ecosystems. Data acquisition from the private sector (food-and feed processing industry) was severely restricted due to confidentiality issues, in agreement with findings of other SFA analyses (Theobald et al. 2016).

Main aspects of the data acquisition for the different subsystems and the complete methodology underlying the computation of each flow including the data sources, assumptions made and references supporting these assumptions are presented in Supplementary Material B. 


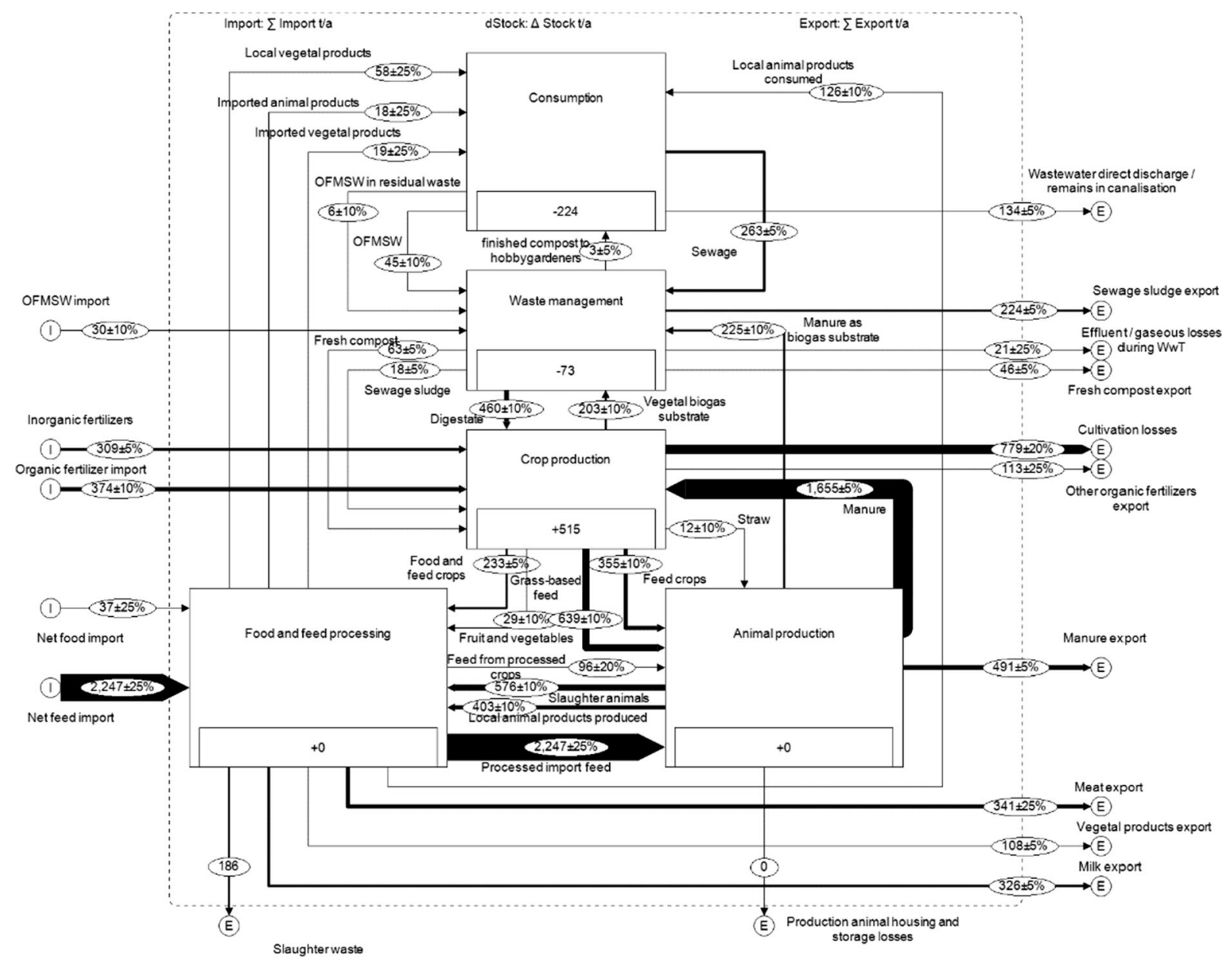

Fig. 2 Phosphorus SFA with flows in ton $y^{-a}{ }^{-1}$. $\mathrm{I}=$ import $\mathrm{E}=$ export. WwT $=$ wastewater treatment

\section{The net import-export dilemma}

It was assumed that the subsystem consumption was firstly supplied with vegetal and animal-sourced food products produced in the district and thereafter supplemented with input from agriculture elsewhere. However, it was taken into account that products not grown in the district, such as citrus fruits, must be imported. This computation was moreover utilized for feed provision, firstly supplying animals with locally sourced feed.

This net import-export approach was undertaken because of lack of data on the origin of food and feed consumed in the district, and lack of data on import and export of products. This is a general limitation of nutrient studies on a regional scale (Harder et al. 2021). Estimation of product import and export were based on the amount of locally consumed and produced feed and food instead. On one hand, this method of flow computation results in maximized local self-sufficiency with regard to food and feed provision. On the other hand, it minimizes the amount of exported products. The relevance of this approach for each subsystem is described under the separate sections (Supplementary material B), while the relevance for the results is evaluated there.

Carbon supply and demand

For the flows (Table 2) with potential as soil amendment and to supply organic $\mathrm{C}$ to soil, first their humus equivalents ( $\mathrm{HE} \mathrm{t}^{-1}$ biomass) were attained from NRW (2015) (Supplementary material C). In brief, the HE describes the potential level of SOM that can accumulate over time from an organic amendment or from a crop. One HE corresponds to $1 \mathrm{~kg} \mathrm{SOM-C}$. The 


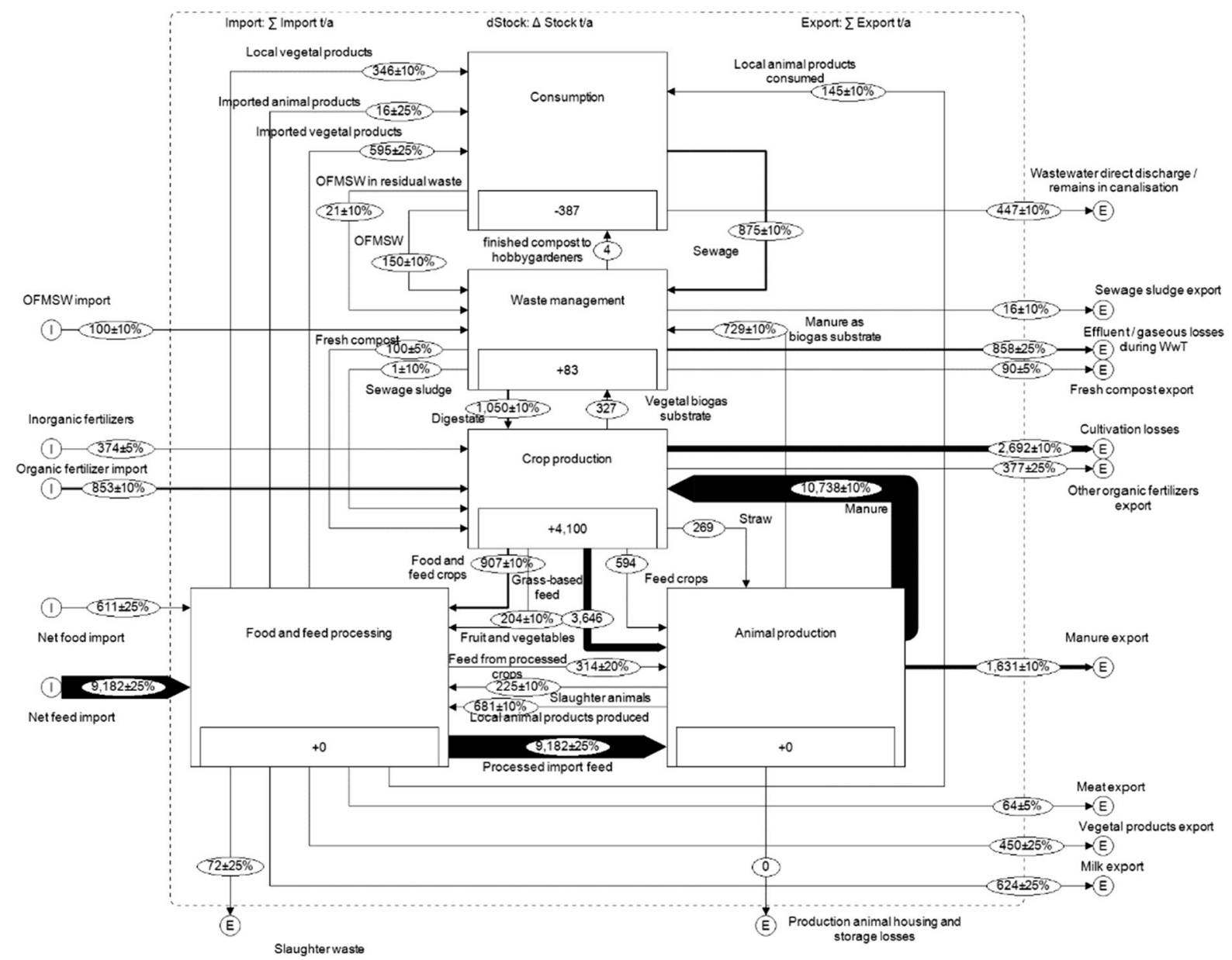

Fig. 3 Potassium SFA with flows in ton year ${ }^{-1}$. $\mathrm{I}=$ import $\mathrm{E}=$ export. WwT $=$ wastewater treatment

HE can also be negative, e.g., when crop management results in an overall reduction of SOM, like for potatoes (NRW 2015). After calculating the HE per crop, the balance between HE supply (i.e. crop residues not harvested from the land and biomass available as soil amendment or fertilizer such as compost) and demand (NRW 2015) (i.e. HE requirements due to harvested crops) was calculated for the entire district. Biomasses considered for soil amendment were: manure currently recycled to crop production in the district and exported manure, digestate from biogas plants, imported and exported organic fertilizer, currently recycled and exported sewage sludge, currently recycled and exported fresh compost and finished compost.
Data reliability

Data used in this study was derived from various types of sources of varying quality. Uncertainty intervals for each flow are presented in Table 1 to provide an indication of the reliability of the sources of information. Uncertainties were defined according to the data uncertainty method presented by Antikainen et al. (2005). Each factor (e.g. nutrient concentrations, mass flows) was assigned an uncertainty level (1-5), based on the source of the information, and a corresponding uncertainty interval $(1,5,10,20$ and 25\%) (Table 1). In this study each nutrient flow was assigned an uncertainty level based on the least certain factor contributing to its calculation. The uncertainty intervals are depicted as standard deviations in Figs. 1, 2 and 3 . 
Table 1 The five uncertainty intervals for various sources of information as used in this study with examples regarding their application to certain data (after Antikainen et al. (2008))

\begin{tabular}{lcll}
\hline Level & Uncertainty interval & Source of information & Examples \\
\hline 1 & $\pm 1 \%$ & Official regional statistics & Population data \\
2 & $\pm 5 \%$ & Official regional official statistics, primary data & Compost and manure data \\
3 & $\pm 10 \%$ & Official national statistics, values from literature & Food consumption data \\
4 & $\pm 20 \%$ & Educated estimate & Food processing by-products data \\
5 & $\pm 25 \%$ & Mass conservation modelling & Net feed import data \\
\hline
\end{tabular}

\section{Results}

Overall system NPK imports and exports

For the agro-food-waste system in the district of Cleves the imports, exports, soil stock changes in crop production and flows between the subsystems (1) crop production, (2) animal production, (3) food and feed processing industry, (4) consumption and (5) waste management were computed in tons nutrient $(\mathrm{N}, \mathrm{P}$ and K) year $^{-1}$ (Figs. 1, 2 and 3). The entire model of the agro-food-waste system includes 40 flows. The 21 largest flows cover at least $90 \%$ of the sum of all studied nutrient flows (Table 2). To improve clarity without losing substantially on accuracy, the remaining smallest 19 flows were included in the analysis and figures but not in Table 2. A table with all the flows of the analysis is shown in Supplementary Material D.

The Cleves district imported a total of 20,791 t N, 2,997 $\mathrm{tP}$ and 11,120 $\mathrm{t} \mathrm{K}$ while 20,293 t N (98\%), 2,000 t P $(67 \%)$ and 4,629 t K (42\%), left the system in agricultural products, organic fertilizers and through losses. Considering only agricultural food products, including exported products and consumption within the district as intended output, results in $\mathrm{N}, \mathrm{P}$ and $\mathrm{K}$ production efficiencies of 25,32 and $15 \%$, respectively. The system's current nutrient self-sufficiency, calculated as the percentage of all input flows stemming from local sources was, 50, 54 and 61\%, respectively for $\mathrm{N}, \mathrm{P}$ and $\mathrm{K}$ (all nutrients supplied to crop production, animal production and local consumption are considered in this calculation). This percentage, therefore, represents the food, feed and fertilizer self-sufficiency. The system needed to import $50 \%, 46 \%$ and $39 \%$ of its required N, P and K.

The largest nutrient import was represented by (net) feed import (54\% of total $\mathrm{N}$ import; $75 \%$ of total $\mathrm{P}$ import; $83 \%$ of total $\mathrm{K}$ import). Inorganic fertilizer was the second largest import for $\mathrm{N}$, while for $\mathrm{P}$ and $\mathrm{K}$ it was manure and other organic fertilizers. Cultivation losses (7482 t N) and housing and storage losses from animal production $(3,282 \mathrm{t} \mathrm{N})$ accounted for the largest removal of $\mathrm{N}$ from the system. Agricultural food products (i.e. all export flows combined), constituted another 3,300 t N (16\%), 775 t P (39\%) and $1,138 \mathrm{t} \mathrm{K}(25 \%)$. The next largest export flow for $\mathrm{N}$ and $\mathrm{P}$ was manure (1880 $\mathrm{t} \mathrm{N}$ and $491 \mathrm{t} \mathrm{P}$ ), while for $\mathrm{K}(1631 \mathrm{t})$ manure represented the largest export flow.

The nutrient ratio in Table 2 shows the NPK stoichiometry of the individual flows. In some flows $\mathrm{N}$ and $\mathrm{K}$ are present at equal amounts, while some are richer in $\mathrm{N}$. The stoichiometry of the inorganic fertilizer import is skewed as single $\mathrm{N}$ fertilizers are imported in larger quantities as compared to inorganic $\mathrm{K}$ and $\mathrm{P}$.

\section{Crop production}

$\mathrm{N}, \mathrm{P}$ and $\mathrm{K}$ entered the crop production subsystem mostly in the form of manure (8469 $\mathrm{t} \mathrm{N}, 1655 \mathrm{t} \mathrm{P}$ and $10,738 \mathrm{t} \mathrm{K})$. This corresponded to $44 \%, 57 \%$ and $82 \%$, respectively, of the total input into crop production. The second largest input for $\mathrm{N}$ was inorganic fertilizer (41\%), while for both P $(13 \%)$ and $\mathrm{K}(7 \%)$ it was imported organic fertilizers (Fig. 4a-c). The largest output of the crop production subsystem for $\mathrm{N}$ were cultivation losses (representing 39\% of all $\mathrm{N}$ output) being almost as high as the inorganic $\mathrm{N}$ import. In contrast, for both $\mathrm{P}$ and $\mathrm{K}$ grass-based feed was the largest output, constituting 40 and $58 \%$ respectively. Based on the calculated balance and leaching rates in literature, this could indicate an accumulation of $515 \mathrm{t}$ $\mathrm{P}$ and $4100 \mathrm{t} \mathrm{K}$ in agricultural soils in the reference year, which corresponds to an average of $7 \mathrm{~kg} \mathrm{P} \mathrm{ha}^{-1}$ 
Table 2 List of the 21 largest nutrient flows of the agro-food-waste system of Cleves district in 2016. Besides the source and destination of each flow, the mass of N, P, K and C (for biomass with potential to use as (source of) bio-based fertilizers) are indicated

\begin{tabular}{|c|c|c|c|c|c|c|c|}
\hline Flow name & Source & Destination & $\begin{array}{l}\mathrm{N} \\
\text { (ton) }\end{array}$ & $\begin{array}{l}\mathrm{P} \\
\text { (ton) }\end{array}$ & $\begin{array}{l}\mathrm{K} \\
\text { (ton) }\end{array}$ & $\begin{array}{l}\mathrm{C} \\
\text { (ton) }\end{array}$ & $\begin{array}{l}\mathrm{N}: \mathrm{P}: \mathrm{K} \\
\text { (weight } \\
\text { based) }\end{array}$ \\
\hline Net feed import & IMPORT & $\begin{array}{l}\text { Food and feed } \\
\text { processing } \\
\text { industry }\end{array}$ & 11,147 & 2247 & 9181 & & $5: 1: 4$ \\
\hline Processed import feed & $\begin{array}{l}\text { Food and feed } \\
\text { processing } \\
\text { industry }\end{array}$ & Animal production & 11,147 & 2247 & 9181 & & $5: 1: 4$ \\
\hline Manure* & Animal production & Crop production & 8469 & 1655 & 10,738 & 75,678 & $5: 1: 6$ \\
\hline Inorganic fertilizers & IMPORT & Crop production & 7864 & 309 & 374 & & $25: 1: 1$ \\
\hline Cultivation losses & Crop production & EXPORT & 7482 & 779 & 2692 & & $10: 1: 3$ \\
\hline Feed crops & Crop production & Animal production & 4055 & 355 & 594 & & $11: 1: 2$ \\
\hline Grass-based feed & Crop production & Animal production & 3985 & 639 & 3646 & & $6: 1: 6$ \\
\hline $\begin{array}{l}\text { Production animal housing and } \\
\text { storage losses }\end{array}$ & Animal production & EXPORT & 3282 & 0 & 0 & & \\
\hline Slaughter animals & Animal production & $\begin{array}{l}\text { Food and feed } \\
\text { processing } \\
\text { industry }\end{array}$ & 2883 & 576 & 225 & & $5: 1: 0.4$ \\
\hline $\begin{array}{l}\text { Local animal products produced } \\
\text { (dairy and eggs) }\end{array}$ & Animal production & $\begin{array}{l}\text { Food and feed } \\
\text { processing } \\
\text { industry }\end{array}$ & 2303 & 403 & 681 & & $6: 1: 2$ \\
\hline Sewage & Consumption & Waste management & 1901 & 263 & 875 & & $7: 1: 3$ \\
\hline Manure export* & Animal production & EXPORT & 1880 & 491 & 1,631 & 12,607 & $4: 1: 3$ \\
\hline Milk export & Animal production & EXPORT & 1771 & 326 & 624 & & $5: 1: 2$ \\
\hline Vegetal biogas substrate & Crop production & Waste management & 1562 & 203 & 327 & & $8: 1: 2$ \\
\hline $\begin{array}{l}\text { Local animal products consumed } \\
\text { (dairy, eggs and meat) }\end{array}$ & $\begin{array}{l}\text { Food and feed } \\
\text { processing } \\
\text { industry }\end{array}$ & Consumption & 1482 & 126 & 145 & & $12: 1: 1$ \\
\hline Effluent / gaseous losses WWTP & Waste management & EXPORT & 1448 & 21 & 858 & & $69: 1: 41$ \\
\hline Digestate* & Waste management & Crop production & 1385 & 460 & 1050 & 7064 & $3: 1: 2$ \\
\hline Crops & Crop production & $\begin{array}{l}\text { Food and feed } \\
\text { processing } \\
\text { industry }\end{array}$ & 1362 & 233 & 907 & & $6: 1: 4$ \\
\hline Organic fertilizer import* & IMPORT & Crop production & 1251 & 374 & 853 & 13,264 & $3: 1: 2$ \\
\hline Meat export & $\begin{array}{l}\text { Food and feed } \\
\text { processing } \\
\text { industry }\end{array}$ & EXPORT & 1004 & 341 & 64 & & $3: 1: 0.2$ \\
\hline Manure as biogas substrate & Animal production & Waste management & 973 & 225 & 729 & & $4: 1: 3$ \\
\hline
\end{tabular}

*A biomass with the potential to recover nutrients for bio-based fertilizers

and $58 \mathrm{~kg} \mathrm{~K} \mathrm{ha}{ }^{-1}$. The nutrient use efficiency (NUE) of crop production was 61,55 and $48 \%$ for $\mathrm{N}, \mathrm{P}$ and $\mathrm{K}$, respectively. For $\mathrm{N}$ this was close to the German average over the period 2010 to 2014 (Eurostat, 2018). For $\mathrm{P}$, however, it is below the average between the years 2009 to 2014 (Eurostat, 2017). The K NUE of the dominant crop in the district, maize, shows a higher $\mathrm{K}$ efficiency in the district compared to literature (Tomaz et al., 2018). 


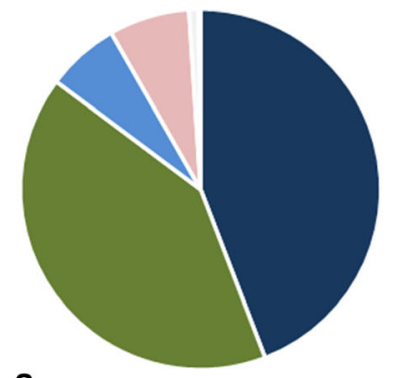

a

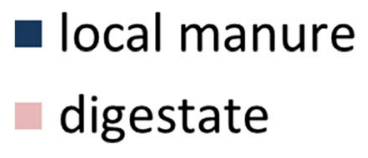

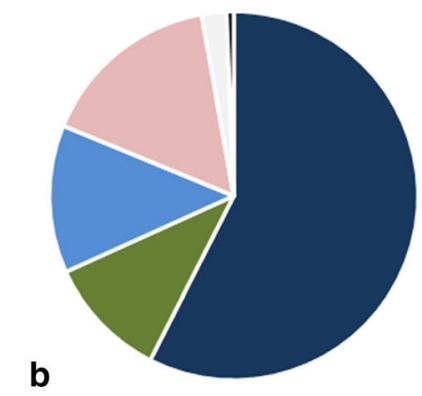

- inorganic fertilizers fresh compost

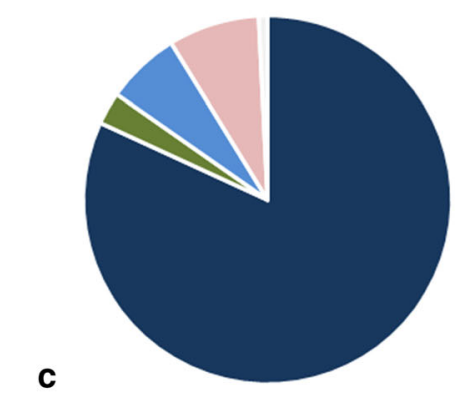

organic fertilizers

- sewage sludge

Fig. 4 Nitrogen a, phosphorus $\mathbf{b}$ and potassium $\mathbf{c}$ input composition into crop production

Animal production

The relative contribution of imported feed to the total input of feed into animal production was $56 \%$ for $\mathrm{N}$, $67 \%$ for $\mathrm{P}$ and $66 \%$ for $\mathrm{K}$. This exemplifies the big dependence of animal production on imported feed, even more so when it is considered that these are minimum values, as the model assumed that all locally produced grass-based feed and locally produced feed crops are fed to livestock in the district. Nevertheless, the presented values are expected to be reasonably representative, as grass-based feed and feed crops are usually not transported over larger distances (Billen et al. 2012).

The overall output of animal products (not including manure) of this subsystem were $5186 \mathrm{t} \mathrm{N}, 979 \mathrm{t} \mathrm{P}$ and $906 \mathrm{t} \mathrm{K}$. The NUE of the animal production subsystem, considering all animal products (including the whole live animal, except for manure), were $26 \%$, $29 \%$ and $6 \%$, for N, P and K, respectively.

Food and feed processing industry

As assumed there were no losses or by-products during processing of imported feed, the import of feed into the food and feed processing industry subsystem equalled the amount of processed feed imported into the animal production subsystem. This same principle applies to food import, adding up to the flows "imported animal products" and "imported vegetal products" representing inputs to consumption. However, in reality, processing of food also generates by- products that are not used as food and emissions and potentially losses can be expected (Wironen et al. 2018).

\section{Consumption}

Based on consumers' diet, the consumption subsystem could have been supplied with a maximum of $2002 \mathrm{t}$ $\mathrm{N}, 185 \mathrm{t} \mathrm{P}$ and $492 \mathrm{t} \mathrm{K}$ originating from locally produced food. For $\mathrm{N}$ and $\mathrm{P}$, this maximum local supply mainly originates from local animal production (74\% of N, $69 \%$ of $\mathrm{P}$ and $30 \%$ of $\mathrm{K}$ ), while for $\mathrm{K}$ this is from local crop production ( $26 \%$ of $\mathrm{N}, 31 \%$ of $\mathrm{P}$ and $70 \%$ of $\mathrm{K}$ ). Results show that the consumption subsystem can be supplied with food from local agriculture to the levels of $86 \%(\mathrm{~N}), 83 \%(\mathrm{P})$ and $83 \%$ (K) of the total consumption. This scenario represents the highest possible local consumption under current production and consumption volumes; certain products (e.g. coffee, fish) that are currently not produced in the district are still to be imported. These values, therefore, represent the maximum level of food selfsufficiency of the district that is possible with current consumption patterns. The minimized export of locally produced food, representing $3300 \mathrm{t} \mathrm{N}, 775 \mathrm{t}$ $\mathrm{P}$ and $1138 \mathrm{t} \mathrm{K}$, consisted of dairy products, meat and vegetal products. However, besides the import of animal products in the form of fish, also additional eggs had to be imported as local production was insufficient. Based on the production and consumption levels the system has an $\mathrm{N}, \mathrm{P}$ and $\mathrm{K}$ self-sufficiency capacity of $236 \%, 471 \%$ and $160 \%$, respectively. 
Comparing the $\mathrm{N}$ food self-sufficiency capacity with that of a peri-urban area (with an $\mathrm{N}$ food selfsufficiency $\leq 170$ ), exemplifies the exporting nature of the district under study (Tedesco et al. 2017).

\section{Waste management}

The waste management subsystem in the district received organic fractions of municipal solid waste (OFMSW) (separately collected from households) and green garden waste from local sources in the Cleves district (including households) (294 t N, $45 \mathrm{t} \mathrm{P}$ and 150 $\mathrm{t} \mathrm{K})$ as well as from surrounding districts $(197 \mathrm{t} \mathrm{N}, 30 \mathrm{t}$ $\mathrm{P}$ and $100 \mathrm{t} \mathrm{K})$. The OFMSW and green garden waste were composted at one single site. The compost was used as soil amendment within the district $(166 \mathrm{t} \mathrm{N}, 63$ t $\mathrm{P}$ and $100 \mathrm{t} \mathrm{K}$ ) or exported (46\% of N, P and $\mathrm{K}$ in compost). A part of the OFMSW was not collected separately but ends up in the residual waste and is concurrently not composted but predominantly incinerated ( $36 \mathrm{t} \mathrm{N}, 6 \mathrm{t} \mathrm{P}$ and $19 \mathrm{t} \mathrm{K}$ ).

Nutrients in sewage amounted to 1,901 t N, $263 \mathrm{tP}$ and $875 \mathrm{t} \mathrm{K}$, of which 24, 92 and $2 \%$ respectively, were retained in the sewage sludge generated by wastewater treatment plants (WwTP). Sewage sludge was in part supplied to agricultural land in the district in 2016 (33 t $\mathrm{N}, 18 \mathrm{t} \mathrm{P}$ and $1 \mathrm{t} \mathrm{K}$ ) (Fig. 5). However, the largest majority of nutrients in sewage sludge left the agrofood-waste system in Cleves as sludge which was either incinerated after which the ashes were landfilled or used elsewhere (420 t N, $224 \mathrm{t} \mathrm{P}$ and $16 \mathrm{t} \mathrm{K}$ ) (Fig. 5). These applications represent losses as the nutrients are left unavailable for the agro-food-waste system. The lumped flows nutrient load in WwTP effluent and (for N) nutrient elements emitted to the atmosphere, mainly as $\mathrm{N}_{2}$ during nitrification, were deduced through mass conservation, subtracting the nutrients

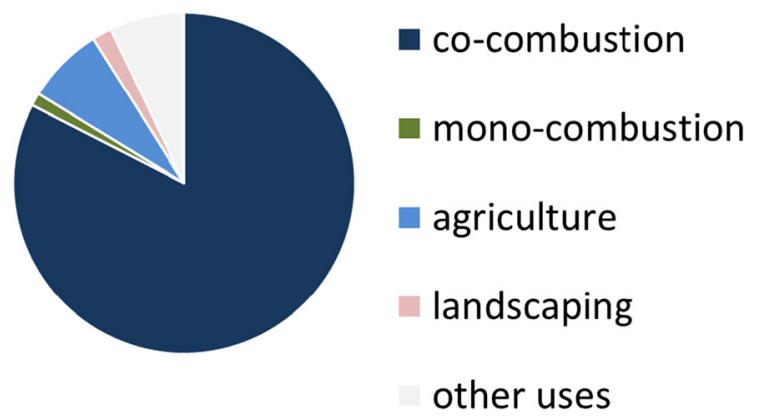

Fig. 5 Fate of sewage sludge in Cleves in 2016 in the sewage sludge from the nutrients in the sewage (1448 t N, $21 \mathrm{t} \mathrm{P}$ and $858 \mathrm{t} \mathrm{K}$ ). These flows were lumped as both represent losses. Also the modelled waste management subsystem $\mathrm{N}$ stock change (1355 t) can be considered as losses, arising during waste treatment (e.g. gaseous $\mathrm{N}$ losses during composting).

One further output flow of the waste management subsystem was digestate from anaerobic digestion of crop- and animal-sourced biomass (1385 t N, 460 t P and $1050 \mathrm{t} \mathrm{K}$ ). Based on the average substrate use in North Rhine-Westphalia, the substrate supplied to biogas plants in the district was a combination of biomass from animal production (manure) (38\% of $\mathrm{N}$, $53 \%$ of $\mathrm{P}$ and $69 \%$ of $\mathrm{K}$ ) and from crop production (crops and by-products) (62\% of N, $47 \%$ of $\mathrm{P}$ and $31 \%$ of $\mathrm{K})$.

As this study only focussed on flows related to the food production system, $\mathrm{P}$ originating from detergent inputs into households was excluded. However, earlier studies determined the substantial contribution of detergents to the $\mathrm{P}$ inputs into households (Theobald et al. 2016). Thus, while $P$ from detergents is not an input, through the household wastewater and ultimately the sewage, it still emerges as an output, resulting in a higher overall $\mathrm{P}$ output than input into consumption (Supplementary Material B). Furthermore, not all the food waste originated from food that was purchased by households, because a part was food waste from commercial sources for which the input was not included in the input to the consumption subsystem. Imbalances were also computed in the waste management subsystem, likely reflecting losses of $\mathrm{N}$ and $\mathrm{K}$ during waste processing, while a negative balance for $\mathrm{P}$ indicates a declining stock of waste.

\section{Carbon supply and demand}

The agricultural land in the district (arable and grassland) was supplied with 222 humus equivalents (HE) of $\mathrm{C} \mathrm{ha}^{-1}$ agricultural land through the application of locally produced manure, digestate, imported organic fertilizer, compost and sewage sludge. However, grasslands are usually fertilized with organic fertilizer to provide $\mathrm{N}, \mathrm{P}$ and $\mathrm{K}$ rather than with organic amendments. The main reason for this is that grasslands are $\mathrm{C}$ sinks due to their permanent vegetation cover and limited soil disturbance and therefore do not demand external $\mathrm{C}$ input through, e.g. organic amendments (Jones et al. 2005). The C supply to the 
more $\mathrm{C}$ demanding arable land, is thus limited by the use of organic fertilizer on grassland. Manure produced in the district $(75,678 \mathrm{t} \mathrm{C})$ contributed the majority of the $C$ (Table 2). Digestate was substantially lower and compost and sewage sludge negligible. Imported and exported organic fertilizer are almost at balance in terms of $\mathrm{C}$. The demand for $\mathrm{HE}$ was calculated to be 257 per ha arable land based on the crops harvested resulting in a $\mathrm{C}$ surplus of $60 \mathrm{HE}$ $\mathrm{ha}^{-1}$ in the district if all organic fertilizers were applied to arable land only (317 HE) (Supplementary Material C). However, as explained above, organic fertilizers are also applied as nutrient source to grassland in the region, where the added $\mathrm{C}$ is not required but may contribute to $\mathrm{C}$ accumulation in those $\mathrm{C}$ rich soils (Fornara et al. 2016). This highlights the relevance of a stoichiometric perspective including $\mathrm{C}$ in the regional evaluation of nutrient flows.

\section{Discussion}

High livestock density and feed import create a nutrient legacy

The district of Cleves is characterized by a high livestock density (2.2 $\mathrm{LLU} \mathrm{ha}^{-1}$ agricultural land), which strongly influences the nutrient balance of the entire agro-food-waste system. On one hand, feed import results in high quantities of $\mathrm{N}, \mathrm{P}$ and $\mathrm{K}$ entering the system, while only a minor part of these nutrients are exported as animal-sourced food products $(25 \%$ of $\mathrm{N}, 30 \%$ of $\mathrm{P}$ and $7 \%$ of $\mathrm{K})$ and as manure $(17 \%$ of $\mathrm{N}$, $22 \%$ of $\mathrm{P}$ and $18 \%$ of $\mathrm{K}$ ). On the other hand, animal production is export-oriented and only $35 \%, 16 \%$ and $18 \%$ of $\mathrm{N}, \mathrm{P}$ and $\mathrm{K}$ present in food products, respectively, are consumed by the local human population. This imbalance between input and output results in a large surplus of nutrients, of which a part is lost (in particular $\mathrm{N}$ ) as a result of agricultural and waste management emissions and discharge, and a part is accumulating (in particular $\mathrm{P}$ and $\mathrm{K}$ ) in agricultural soils. For $\mathrm{N}$, for example, 13,182 t N (63\% of the total $\mathrm{N}$ import) is lost from the system. Losses from agricultural production only (crop production and animal production), correspond to $150 \mathrm{~kg} \mathrm{~N} \mathrm{ha}^{-1}$ agricultural land. For every $\mathrm{kg}$ of product- $\mathrm{N}$ there are about three $\mathrm{kg} \mathrm{N}$ livestock related losses, including losses during animal housing, manure storage and manure application. The nutrient quantities in manure produced by the livestock sector are, furthermore, far in excess of crop demand (Bateman et al. 2011; Schipanski and Bennett 2012). Moreover, additional $\mathrm{N}$ deposition in the district being somewhere between 11 and $30 \mathrm{~kg} \mathrm{~N} \mathrm{ha}^{-1} \mathrm{yr}^{-1}$ (Wendland et al. 2020) was not included in the analysis, and needs to be considered to cover all inputs and losses. Together, the total sum of inputs have an important impact on nutrient saturation of soils (Senthilkumar et al. 2012) and liquid and gaseous losses of $\mathrm{N}$ causing environmental effects in groundwater, aquatic and terrestrial ecosystems also beyond the district. Utilizing average leaching rates $(11 \mathrm{~kg} \mathrm{P}$ $\mathrm{ha}^{-1} \mathrm{yr}^{-1}$ ) (Schoumans 2015) for Dutch agricultural soils, with a high degree of $\mathrm{P}$ saturation, resulted in 779 t P losses in Cleves in 2016. Utilizing K leaching losses for the most common crop (maize silage) (38 $\mathrm{kg} \mathrm{ha}^{-1} \mathrm{yr}^{-1}$ ) as presented by Kayser et al. (2012), results in 4,100 t of K accumulating in Cleves' agricultural soils and $2692 \mathrm{t} \mathrm{K}$ lost, again showing the large nutrient use inefficiency of the animal production subsystem, leaving a nutrient legacy in soil and the environment.

\section{Local improvement options}

Organic fertilizers do not have the same quality as inorganic fertilizers as the latter can precisely fulfil the specific stoichiometric nutrient demand of crops which results in a higher nutrient use efficiency (Cardenas et al. 2019; Sharif et al. 2004). This is in particular the case for high value and high nutrient demanding crops, such as vegetables and some cash crops. Inorganic fertilizers are therefore preferred by farmers for certain crops. Nonetheless, solely on a mass basis locally recycled manure covers 72, 104 and $170 \%$ of the required $\mathrm{N}, \mathrm{P}$ and $\mathrm{K}$ in total crop production. However, for the most common crops in the district, being maize ( $33 \%$ of arable land), winter wheat ( $21 \%$ of arable land) and potato ( $12 \%$ of arable land), nutrient demand cannot be matched with manure, the biggest mass flow, because of nutrient stoichiometry. This analysis does not consider grassland as inorganic fertilizers are generally not applied to grassland and therefore substitution by organic fertilizers does not have to be considered (NRW 2018). The NPK ratio of manure is $5: 1: 6$, whereas the nutrient ratio requirements of maize, winter wheat and 
potato are 7:1:5, 6:1:3 and 6:1:8, respectively (supplementary material $\mathrm{D}$ ), while in practice even more $\mathrm{N}$ is needed due to limited $\mathrm{N}$ availability from the manure. Direct application according to $\mathrm{N}$ crop requirements would result in exceeding EU nutrient application limits for Germany (six-year average of $20 \mathrm{~kg} \mathrm{P}_{2} \mathrm{O}_{5} \mathrm{ha}^{-1} \mathrm{yr}^{-1}$ ) and in particular causing $\mathrm{P}$ application in excess and accumulation over time (Bittman et al. 2017; Jakobsen 1993; Kuhn et al. 2018; Little et al. 2015). In addition to manure, also wastes produced by humans (e.g. sewage, OFMSW) hold potential as source of plant nutrients. Despite the relatively low contribution of waste management flows to total nutrient flows (10\%), as compared to those related to agriculture in the district of Cleves their significance for nutrient self-sufficiency of the whole system will be higher in urban areas, with increasing urbanization (Neset et al. 2010) and with increasing circularity in agriculture. Considering the NPK ratio of sewage sludge, of 2:1:0.1, the same issue arises with direct application as with manure, causing $\mathrm{P}$ excess and $\mathrm{K}$ limitation. However, considering a local SOM decline as reported in literature (Steinmann et al. 2016), recycling of all organic $C$ contained in the biomass is desired and could contribute to SOM maintenance in the arable soils in the district of Cleves (Steinmann et al. 2016). Overall, to improve nutrient self-sufficiency for N, P, K and C, the system needs to be either adapted to produce less biomass with an $\mathrm{N}: \mathrm{P}: \mathrm{K}: \mathrm{C}$ ratio which, however, will not fit the crop specific demand for those nutrients (e.g. manure) leaving some nutrient unused, or biomass needs to be processed to allow precision fertilization of single nutrients. The latter case would also allow the export of any excess nutrients.

\section{Identifying technological intervention with high potential to improve circularity}

The agro-food-waste system of district Cleves exported $2883 \mathrm{t} \mathrm{N}, 884 \mathrm{t} \mathrm{P}$ and $2114 \mathrm{t} \mathrm{K}$ in biomasses that could potentially be used as fertilizers. These exported biomasses had, on a mass basis, the potential to replace $37 \%, 286 \%$ and $565 \%$, respectively of the $\mathrm{N}, \mathrm{P}$ and $\mathrm{K}$ imported as inorganic fertilizers. Recycling of manure requires safe and economically viable technologies recovering single nutrients for local application, while excess nutrients are recovered in a form which can be exported economically. A range of mechanical separation technological options allows for isolating nutrients from manure which can replace inorganic fertilizers while also conserving organic C (Sigurnjak et al. 2017; Vaneeckhaute et al. 2013). Struvite precipitation for example can provide a phosphorus source from manure as well as sewage (Ackerman et al. 2013; Le Corre et al. 2009). However, there is a deficiency of $\mathrm{C}$ when biomass is also directly applied to grassland. The multi-nutrient perspective combined with $\mathrm{C}$ for biomasses with potential to process into bio-based fertilizers indicates that in order to provide arable soil with sufficient $\mathrm{C}$, biomass will have to be processed. Recovering nutrients would allow for nutrients to be supplied to arable soils and grassland, while the $\mathrm{C}$ demand of cultivated crops can be met to conserve $\mathrm{C}$ soil stocks and with that soil fertility.

Human waste management currently focuses on nutrient removal rather than on recycling (Coppens et al. 2016; Theobald et al. 2016; Verger et al. 2018). Legislation in Germany obliges WwTP as of 2032 to recover all $\mathrm{P}$ and recycle this to agriculture (Heidecke 2018). This contributes to planned changes in district Cleves to recover nutrients in local WwTP's. However, direct application of sewage sludge is therewith no longer allowed which hinders the recycling of other nutrients. Technologies which recover $\mathrm{N}, \mathrm{P}$ and $\mathrm{K}$, such as membrane and ultrafiltration, are preferred, as they allow for creation of tailor made fertilizers, fulfilling the stoichiometric nutrient demand of arable crops and vegetables (Zhang et al. 2014).

To implement technological measures, a shift in farm practices is required to allow the replacement of inorganic NPK fertilizers (Hanserud et al. 2016; Verger et al. 2018). However, in the future increasing extraction costs for phosphate rock might give incentives to replace it with bio-based fertilizers (Cordell et al. 2009). Moreover, possibilities of processing nutrient-rich biomasses, such as manure, to bio-based fertilizer in order to recycle $\mathrm{N}, \mathrm{P}, \mathrm{K}$ and organic $\mathrm{C}$ in the district need to be more thoroughly evaluated considering their applicability as well as their ecological, economic and social impact. In this context, the stoichiometry of crop nutrient demand as well as the stoichiometry of SOM need to be considered to allow for a truly sustainable nutrient recovery and soil fertility management including the $\mathrm{C}$ component.

Ultimately, excess nutrients will have to be exported to areas with nutrient demand when 
agricultural production, in particular animal production, in the district of Cleves, remains dependent on feed import. However, given the manure export from Cleves' neighbouring districts, distribution beyond the district might result in an area-wide nutrient surplus beyond feasible transport distances (NRW 2018). Facilitating biomass transport from areas with supply to those with nutrient demand, both inside the district as well as to neighbouring districts, could improve nutrient cycling. However, analyses of nutrient flows at multi-local and sub-local perspectives are needed to identify demand and supply (Cooper and CarliellMarquet 2013; Wendland et al. 2020), therefore shaping the perspective of nutrient circularity in food systems.

\section{Identifying systemic changes with high potential to improve circularity}

Beyond technological measures, systemic changes are ultimately required to address the imbalance in nutrient supply and demand due to specialization in agricultural production with animal production relying on feed import. Thus, in a circular system, nutrients from surplus areas must be returned to areas of feed crop cultivation. The net input-output approach taken in this study assumes maximum local feed self-sufficiency under current crop and animal production practices. However, even under this assumption import of feed is required to feed the livestock in the district which produce large quantities of products for export. Uwizeye et al. (2020) found that reducing imports of feed for livestock, can contribute to a reduced surplus of N, P and $\mathrm{K}$ in the system. In a circular agricultural system, a role of animals is especially to utilize and upgrade biomass unsuitable or undesired for human consumption, such as by-products from food processing, and change them into highly nutritious food (Röös et al. 2016; Van Zanten et al. 2014). The utilization of land only suitable as grassland is moreover a valuable role of animals in a circular system (Van Zanten et al. 2018). In the case of grassland it needs to be considered whether land is not rather used for crop production as utilizing land for crop production for human consumption is more efficient (Mottet et al. 2017). However, grassland contributes to $\mathrm{C}$ sequestration and biodiversity conservation, while the conversion to arable land causes soil $\mathrm{C}$ and biodiversity loss
(Bretagnolle et al. 2011; Lal 2004; Van Zanten et al. 2018). This means that the size of the livestock population in a system depends on the available feed in that system. Applying this to Cleves would ultimately imply a decrease of the livestock density in the district (Granstedt et al. 2008; Senthilkumar et al. 2012; Van Zanten et al. 2014; Wironen et al. 2018). The system's feed self-sufficiency of $44 \%$ for N, 33\% for P and 34\% for $\mathrm{K}$ implies that a maximum of $33 \%$ of the 156,098 LLU that were present in 2016 could have been fed with locally produced feed (grass-based feed, feed crops and feed from processed crops). Considering this reduction in livestock numbers, the resulting decline in available manure, and the extent to which local biomass can cover the cultivated crops' demand for $\mathrm{C}$ under the current situation, it becomes apparent that other biomass flows are required to be used efficiently to fulfil N, P, K and C demand. To estimate the potential of feeding with locally produced feed, more data on food processing by-products is required and could be collected through participatory research (Metson et al. 2012). Optimising recycling of biomass and adjusting the local livestock number to available feed, would reduce the production of animal-sourced food. As a consequence of reduced livestock numbers, the export of animal-sourced food will be reduced, creating demand for food production elsewhere. Circular agriculture, therefore, inherently means a reduction in the consumption of animal products, or the problems related to high livestock numbers is likely to shift to another, potentially less favourable, area. However, sourcing feed locally can provide additional revenues to industry providing by-products and supporting local nutrient circularity and lower emissions of nutrients (Seddighi and Thomas 2011). Moreover, farmers would not depend on fluctuating feed prices and improve their economic independency. Feed exporting areas in turn would not remove N, P, K and organic matter from the soils by exporting the feed and not recovering the resulting nutrients contained in the manure (Craswell et al. 2004; Jones et al. 2013).

\section{Outlook}

The net input-output approach taken in this study allows nutrient flow analyses to be done despite lack of data on import and export of food and feed products of a certain area. It gives moreover an insight into the potential nutrient self-sufficiency of an area. However, 
it does not represent necessarily the actual situation as the district, for example, exports part of its harvested grass. Moreover, the spatial variation with regard to nutrient surplus within the studied area (Wendland et al. 2020) was not addressed in this study, but would be required for local implementation of means to reduce nutrient surplus and restore nutrient cycles. The results indicate that especially for the subsystem foodand feed processing industry more data is required in order to determine the district's self-sufficiency more accurately. The present analysis, therefore, illustrates a starting point to analyse quantitative effects of promising changes, e.g. through scenario studies, towards nutrient self-sufficiency and improved nutrient circularity. This study, furthermore, may serve as a methodical blueprint for others who aim to analyse local nutrient flows in agro-food-waste systems.

\section{Conclusions}

This multi-nutrient flow analysis with a local perspective indicates that the primary flows in the agro-foodwaste system in district Cleves are related to agriculture, especially to animal production. The large imports of feed and inorganic fertilizers and the low levels of nutrients exported in food, illustrate the linear nature of the agro-food-waste system in the district and explains the nutrient surplus. Currently, animal husbandry is highly dependent on feed import, with $56 \%$ of $\mathrm{N}, 67 \%$ of $\mathrm{P}$ and $66 \%$ of $\mathrm{K}$ in annual feed uptake being imported. Consequently, the application of locally generated manure contributes to large losses to the environment (7482 t N, $779 \mathrm{t} \mathrm{P}$ and $2692 \mathrm{t} \mathrm{K}$ ). This study denotes that system change with regard to animal production, namely reducing livestock numbers based on local feed supply, using grasslands and by-products from food processing, and linking it to local crop demand could support a more circular agrofood-waste system. Through the implementation of technologies for the production of bio-based fertilizers, biomass can replace inorganic fertilizers. On a mass basis, currently exported biomass has the potential to replace 37,286 and $565 \%$, respectively of the N, $\mathrm{P}$ and $\mathrm{K}$ imported as inorganic fertilizers. While, local recycling is desired to reach a self-sufficient local system and conserve organic $\mathrm{C}$, direct application of biomass results in oversupply of especially $\mathrm{P}$ due to imbalanced nutrient stoichiometry of supply and demand. Therefore, future research should aim at balancing crop-and animal production and evaluating the potential of technologies for creating bio-based fertilizers to facilitate a more circular agro-food-waste system.

Acknowledgements The authors are grateful for the financial support from the EU INTERREG V A project Food Pro $\cdot$ tec.ts https://www.foodprotects.eu/nl/ (funded by the European Regional Development Fund) and the input of stakeholders in the district for the role they took in data provision. In particularly the input of Dr. Horst Gömann (Landwirtschaftskammer Nordrhein-Westfalen) and Suzanne van Loosbroek is appreciated

Open Access This article is licensed under a Creative Commons Attribution 4.0 International License, which permits use, sharing, adaptation, distribution and reproduction in any medium or format, as long as you give appropriate credit to the original author(s) and the source, provide a link to the Creative Commons licence, and indicate if changes were made. The images or other third party material in this article are included in the article's Creative Commons licence, unless indicated otherwise in a credit line to the material. If material is not included in the article's Creative Commons licence and your intended use is not permitted by statutory regulation or exceeds the permitted use, you will need to obtain permission directly from the copyright holder. To view a copy of this licence, visit http://creativecommons.org/licenses/by/4.0/.

\section{References}

Ackerman JN, Zvomuya F, Cicek N, Flaten D (2013) Evaluation of manure-derived struvite as a phosphorus source for canola. Can J Plant Sci 93(3):419-424

Antikainen R, Haapanen R, Lemola R, Nousiainen JI, Rekolainen S (2008) Nitrogen and phosphorus flows in the Finnish agricultural and forest sectors, 1910-2000. Water Air Soil Pollut 194(1-4):163-177

Antikainen R, Lemola R, Nousiainen JI, Sokka L, Esala M, Huhtanen P, Rekolainen S (2005) Stocks and flows of nitrogen and phosphorus in the Finnish food production and consumption system. Agr Ecosyst Environ 107(2-3):287-305

Bateman A, van der Horst D, Boardman D, Kansal A, CarliellMarquet C (2011) Closing the phosphorus loop in England: the spatio-temporal balance of phosphorus capture from manure versus crop demand for fertiliser. Resour Conserv Recycl 55(12):1146-1153. https://doi.org/10.1016/j. resconrec.2011.07.004

Bellarby J, Surridge BWJ, Haygarth PM, Liu K, Siciliano G, Smith L, Meng F (2018) The stocks and flows of nitrogen, phosphorus and potassium across a 30-year time series for agriculture in Huantai county, China. Sci Total Environ 
619-620:606-620. https://doi.org/10.1016/j.scitotenv. 2017.10.335

Billen G, Barles S, Chatzimpiros P, Garnier J (2012) Grain, meat and vegetables to feed Paris: where did and do they come from? Localising Paris food supply areas from the eighteenth to the twenty-first century. Reg Environ Change 12(2):325-335

Bittman S, Sheppard SC, Poon D, Hunt DE (2017) Phosphorus flows in a peri-urban region with intensive food production: A case study. J Environ Manage 187:286-297. https:// doi.org/10.1016/j.jenvman.2016.11.040

Bretagnolle V, Gauffre B, Meiss H, Badenhausser I (2011) The role of grassland areas within arable cropping systems for the conservation of biodiversity at the regional level. Grassland Productivity and Ecosystem Services. G. Lemaire, JA Hodgson and A. Chabbi, 251-260

Brunner PH, Rechberger H (2016) Practical handbook of material flow analysis. CRC Press, USA

Bučiene A, Švedas A, Antanaitis Š (2003) Balances of the major nutrients N, P and $\mathrm{K}$ at the farm and field level and some possibilities to improve comparisons between actual and estimated crop yields. Eur J Agron 20(1-2):53-62. https:// doi.org/10.1016/S1161-0301(03)00073-X

Cardenas L, Bhogal A, Chadwick D, McGeough K, Misselbrook T, Rees R, Smith K (2019) Nitrogen use efficiency and nitrous oxide emissions from five UK fertilised grasslands. Sci Total Environ 661:696-710

Cencic O, Rechberger H (2008) Material flow analysis with software STAN. Paper presented at the EnviroInfo

Chowdhury RB, Moore GA, Weatherley AJ (2018) A multi-year phosphorus flow analysis of a key agricultural region in Australia to identify options for sustainable management. Agric Syst 161:42-60. https://doi.org/10.1016/j.agsy.2017. 12.005

Chowdhury RB, Moore GA, Weatherley AJ, Arora M (2014) A review of recent substance flow analyses of phosphorus to identify priority management areas at different geographical scales. Resour Conserv Recycl 83:213-228

Cooper J, Carliell-Marquet C (2013) A substance flow analysis of phosphorus in the UK food production and consumption system. Resour Conserv Recycl 74:82-100

Coppens J, Meers E, Boon N, Buysse J, Vlaeminck SE (2016) Follow the $\mathrm{N}$ and $\mathrm{P}$ road: High-resolution nutrient flow analysis of the Flanders region as precursor for sustainable resource management. Resour Conserv Recycl 115:9-21. https://doi.org/10.1016/j.resconrec.2016.08.006

Cordell D, Drangert J-O, White S (2009) The story of phosphorus: global food security and food for thought. Glob Environ Chang 19(2):292-305

Cordell D, White S (2015) Tracking phosphorus security: indicators of phosphorus vulnerability in the global food system. Food Security 7(2):337-350. https://doi.org/10. 1007/s12571-015-0442-0

Craswell ET, Grote U, Henao J, Vlek PL (2004) Nutrient flows in agricultural production and international trade: Ecological and policy issues. Retrieved from

De Vries W, Kros J, Kroeze C, Seitzinger SP (2013) Assessing planetary and regional nitrogen boundaries related to food security and adverse environmental impacts. Current Opin Environ Sustain 5(3-4):392-402. https://doi.org/10.1016/j. cosust.2013.07.004
Eder G (2001) Stickstoff-Phosphor-und Kaliumauswaschung bei Wirtschaftsdüngeranwendung im Grün-und Ackerland: na.

Eurostat (2017) Agri-environmental Indicator Risk of Pollution by Phosphorus

Eurostat (2018) Eurostat statistics explained. Agri-environmental indicator-gross nitrogen balance. April

Fischer P, Pöthig R, Venohr M (2017) The degree of phosphorus saturation of agricultural soils in Germany: current and future risk of diffuse $\mathrm{P}$ loss and implications for soil $\mathrm{P}$ management in Europe. Sci Total Environ 599-600:1130-1139. https://doi.org/10.1016/j.scitotenv. 2017.03.143

Fornara DA, Wasson E-A, Christie P, Watson CJ (2016) Longterm nutrient fertilization and the carbon balance of permanent grassland: any evidence for sustainable intensification? Biogeosciences 13(17):4975-4984

Granstedt A, Schneider T, Seuri P, Thomsson O (2008) Ecological recycling agriculture to reduce nutrient pollution to the baltic sea. Biol Agric Hortic 26(3):279-307. https://doi. org/10.1080/01448765.2008.9755088

Hanserud OS, Brod E, Øgaard AF, Müller DB, Brattebø H (2016) A multi-regional soil phosphorus balance for exploring secondary fertilizer potential: the case of Norway. Nutr Cycl Agroecosyst 104(3):307-320. https://doi. org/10.1007/s10705-015-9721-6

Harder R, Giampietro M, Smukler S (2021) Towards a circular nutrient economy. A novel way to analyze the circularity of nutrient flows in food systems. Resour Conserv Recycl 172:105693. https://doi.org/10.1016/j.resconrec.2021. 105693

Häußermann U, Klement L, Breuer L, Ullrich A, Wechsung G, Bach M (2020) Nitrogen soil surface budgets for districts in Germany 1995 to 2017. Environ Sci Eur 32(1):1-14

Heidecke ARP (2018) Sewage sludge disposal in the Federal Republic of Germany Retrieved from https://www. umweltbundesamt.de/en/publikationen/sewage-sludgedisposal-in-the-federal-republic-of

Jakobsen ST (1993) Nutritional disorders between potassium, magnesium, calcium, and phosphorus in soil. Plant Soil 154(1):21-28. https://doi.org/10.1007/BF00011066

Joergensen RG, Wichern F (2018) Alive and kicking: why dormant soil microorganisms matter. Soil Biol Biochem 116:419-430. https://doi.org/10.1016/j.soilbio.2017.10. 022

Jones DL, Cross P, Withers PJ, DeLuca TH, Robinson DA, Quilliam RS, Edwards-Jones G (2013) Nutrient stripping: the global disparity between food security and soil nutrient stocks. J Appl Ecol 50(4):851-862

Jones S, Rees R, Skiba U, Ball B (2005) Greenhouse gas emissions from a managed grassland. Global Planet Change 47(2-4):201-211

Jurgilevich A, Birge T, Kentala-Lehtonen J, Korhonen-Kurki K, Pietikäinen J, Saikku L, Schösler H (2016) Transition towards circular economy in the food system. Sustainability 8(1):69

Kallenbach CM, Frey SD, Grandy AS (2016) Direct evidence for microbial-derived soil organic matter formation and its ecophysiological controls. Nat Commun. https://doi.org/ $10.1038 /$ ncomms 13630 
Kayser M, Benke M, Isselstein J (2012) Potassium leaching following silage maize on a productive sandy soil. Plant Soil Environ 58(12):545-550

Kayser M, Isselstein J (2005) Potassium cycling and losses in grassland systems: a review. Grass Forage Sci 60(3):213-224

Klinglmair M, Lemming C, Jensen LS, Rechberger H, Astrup TF, Scheutz C (2015) Phosphorus in Denmark: national and regional anthropogenic flows. Resour Conserv Recycl 105:311-324. https://doi.org/10.1016/j.resconrec.2015.09. 019

Kuhn T, Kokemohr L, Holm-Müller K (2018) A life cycle assessment of liquid pig manure transport in line with EU regulations: a case study from Germany. J Environ Manage 217:456-467. https://doi.org/10.1016/j.jenvman.2018.03. 082

Kuokkanen A, Mikkilä M, Kuisma M, Kahiluoto H, Linnanen L (2017) The need for policy to address the food system lockin: a case study of the Finnish context. J Clean Prod 140:933-944. https://doi.org/10.1016/j.jclepro.2016.06. 171

Lal R (2004) Soil carbon sequestration impacts on global climate change and food security. Science 304(5677):1623-1627. https://doi.org/10.1126/science. 1097396

Le Corre KS, Valsami-Jones E, Hobbs P, Parsons SA (2009) Phosphorus recovery from wastewater by struvite crystallization: a review. Crit Rev Environ Sci Technol 39(6):433-477

Le Noë J, Billen G, Esculier F, Garnier J (2018) Long-term socioecological trajectories of agro-food systems revealed by $\mathrm{N}$ and $\mathrm{P}$ flows in French regions from 1852 to 2014 . Agr Ecosyst Environ 265:132-143. https://doi.org/10.1016/j. agee.2018.06.006

Little NG, Mohler CL, Ketterings QM, DiTommaso A (2015) Effects of organic nutrient amendments on weed and crop growth. Weed Sci 63(3):710-722. https://doi.org/10.1614/ WS-D-14-00151.1

Maurer M, Muncke J, Larsen T (2002) Technologies for nitrogen recovery and reuse. Lens $\mathrm{P}$, Hulshoff Pol L, Wilderer $\mathrm{P}$, Asano, 491-510.

Mehta C, Tucker R, Poad G, Davis R, McGahan E, Galloway J, Batstone D (2016) Nutrients in Australian agro-industrial residues: production, characteristics and mapping. Australas J Environ Manage 23(2):206-222. https://doi.org/10. 1080/14486563.2016.1151838

Metson GS, Aggarwal R, Childers DL (2012) Efficiency through proximity: changes in phosphorus cycling at the urban-agricultural interface of a rapidly urbanizing desert region. J Ind Ecol 16(6):914-927

Miltner A, Bombach P, Schmidt-Brücken B, Kästner M (2012) SOM genesis: microbial biomass as a significant source. Biogeochemistry 111(1-3):41-55. https://doi.org/10.1007/ s10533-011-9658-z

Moinard V, Levavasseur F, Houot S (2021) Current and potential recycling of exogenous organic matter as fertilizers and amendments in a French peri-urban territory. Resour Conserv Recycl 169:105523

Mottet A, de Haan C, Falcucci A, Tempio G, Opio C, Gerber P (2017) Livestock: on our plates or eating at our table? A new analysis of the feed/food debate. Glob Food Sec $14: 1-8$

Neset T-SS, Drangert J-O, Bader H-P, Scheidegger R (2010) Recycling of phosphorus in urban Sweden: a historical overview to guide a strategy for the future. Water Policy 12(4):611-624

NRW L (2014) Nährstoffbericht NRW 2014. Münster, Germany: Landwirtschaftskammer Nordrhein-Westfalen.[Google Scholar]

NRW L (2015) Humus und Bodenfruchtbarkeit. Münster, Germany: Landwirtschaftskammer Nordrhein-Westfalen.[Google Scholar]

NRW L (2018) Nährstoffbericht 2017 über Wirtschaftsdünger und andere organische Dünger. Hg. v. Direkt der Landwirtschaftskammer Nordrhein-Westfalen als Landesbeauftragter. Landwirtschaftskammer NRW. Münster, zuletzt geprüft am, 8, 2019

Paul EA (2016) The nature and dynamics of soil organic matter: plant inputs, microbial transformations, and organic matter stabilization. Soil Biol Biochem 98:109-126. https://doi. org/10.1016/j.soilbio.2016.04.001

Regionalstatistik (2021) Gebietsfläche in qkm - Stichtag 31.12. regionale Tiefe: Kreise und krfr. Städte. Retrieved from https://www.regionalstatistik.de/genesis// online? operation $=$ table $\&$ code $=11111-01-01-4 \&$ bypass $=$ true\&levelindex $=1 \&$ levelid $=$ 1610380976102\#abreadcrumb

Röös E, Patel M, Spångberg J, Carlsson G, Rydhmer L (2016) Limiting livestock production to pasture and by-products in a search for sustainable diets. Food Policy 58:1-13. https://doi.org/10.1016/j.foodpol.2015.10.008

Santos WO, Mattiello EM, Pacheco AA, Vergutz L, da Silva Souza-Filho LF, Abdala DB (2017) Thermal treatment of a potassium-rich metamorphic rock in formation of soluble K forms. Int J Miner Process 159:16-21. https://doi.org/10. 1016/j.minpro.2016.12.004

Schipanski ME, Bennett EM (2012) The influence of agricultural trade and livestock production on the global phosphorus cycle. Ecosystems 15(2):256-268. https://doi.org/ 10.1007/s10021-011-9507-x

Schoumans OF (2015) Phosphorus leaching from soils: process description, risk assessment and mitigation: Alterra, Wageningen-UR

Seddighi H, Thomas K (2011) Economic returns of using brewery's spent grain in animal feed. World Acad Sci Eng Technol 74:701-705

Senthilkumar K, Nesme T, Mollier A, Pellerin S (2012) Regional-scale phosphorus flows and budgets within France: the importance of agricultural production systems. Nutr Cycl Agroecosyst 92(2):145-159. https://doi.org/10. 1007/s10705-011-9478-5

Sharif M, Ahmad M, Sarir M, Khattak R (2004) Effect of organic and inorganic fertilizers on the yield and yield componentsof maize. Pakistan Journal of Agriculture, Agricultural Engineering Veterinary Sciences (Pakistan)

Sigurnjak I, Vaneeckhaute C, Michels E, Ryckaert B, Ghekiere G, Tack FMG, Meers E (2017) Fertilizer performance of liquid fraction of digestate as synthetic nitrogen substitute in silage maize cultivation for three consecutive years. Sci Total Environ 599-600:1885-1894. https://doi.org/10. 1016/j.scitotenv.2017.05.120 
Sipert S, Cohim E, do Nascimento FRA (2020) Identification and quantification of main anthropogenic stocks and flows of potassium in Brazil. Environ Sci Pollut Res Int 27:32579

Steinmann T, Welp G, Holbeck B, Amelung W (2016) Longterm development of organic carbon contents in arable soil of North Rhine-Westphalia, Germany, 1979-2015. Eur J Soil Sci 67(5):616-623. https://doi.org/10.1111/ejss.12376

Tedesco C, Petit C, Billen G, Garnier J, Personne E (2017) Potential for recoupling production and consumption in peri-urban territories: the case-study of the Saclay plateau near Paris, France. Food Policy 69:35-45. https://doi.org/ 10.1016/j.foodpol.2017.03.006

Theobald TFH, Schipper M, Kern J (2016) Regional phosphorus flows Berlin-Brandenburg phosphorus flows in BerlinBrandenburg, a regional flow analysis. Resour Conserv Recycl 112:1-14. https://doi.org/10.1016/j.resconrec. 2016.04.008

Tomaz A, Patanita M, Guerreiro I, Dôres J, Boteta L, Palma JF (2018) Efficient use of water and nutrients in irrigated cropping systems in the Alqueva region. Spanish Journal of Soil Science, $8(1)$

Treadwell JL, Clark OG, Bennett EM (2018) Dynamic simulation of phosphorus flows through Montreal's food and waste systems. Resour Conserv Recycl 131:122-133. https://doi.org/10.1016/j.resconrec.2017.12.018

Uwizeye A, de Boer IJM, Opio CI, Schulte RPO, Falcucci A, Tempio G, Gerber PJ (2020) Nitrogen emissions along global livestock supply chains. Nature Food 1(7):437-446. https://doi.org/10.1038/s43016-020-0113-y

van der Wiel BZ, Weijma J, van Middelaar CE, Kleinke M, Buisman CJN, Wichern F (2020) Restoring nutrient circularity: a review of nutrient stock and flow analyses of local agro-food-waste systems. Resour Conserv Recycl. https://doi.org/10.1016/j.resconrec.2020.104901

Van Grinsven HJ, Rabl A, De Kok TM (2010) Estimation of incidence and social cost of colon cancer due to nitrate in drinking water in the EU A tentative cost-benefit assessment. Environ Health Glob Access Sci Source. https://doi. org/10.1186/1476-069X-9-58

Van Ittersum MK, Van Bussel LGJ, Wolf J, Grassini P, Van Wart J, Guilpart N, Cassman KG (2016) Can sub-Saharan Africa feed itself? Proc Natl Acad Sci USA
113(52):14964-14969. https://doi.org/10.1073/pnas. 1610359113

Van Vuuren DP, Bouwman AF, Beusen AH (2010) Phosphorus demand for the 1970-2100 period: a scenario analysis of resource depletion. Glob Environ Chang 20(3):428-439

Van Zanten HH, Herrero M, Van Hal O, Röös E, Muller A, Garnett T, De Boer IJ (2018) Defining a land boundary for sustainable livestock consumption. Glob Change Biol 24(9):4185-4194

Van Zanten HHE, Mollenhorst H, De Vries JW, Van Middelaar CE, Van Kernebeek HRJ, De Boer IJM (2014) Assessing environmental consequences of using co-products in animal feed. Int J Life Cycle Assess 19(1):79-88. https://doi. org/10.1007/s11367-013-0633-x

Vaneeckhaute C, Meers E, Michels E, Buysse J, Tack FMG (2013) Ecological and economic benefits of the application of bio-based mineral fertilizers in modern agriculture. Biomass Bioenerg 49:239-248. https://doi.org/10.1016/j. biombioe.2012.12.036

Verger Y, Petit C, Barles S, Billen G, Garnier J, Esculier F, Maugis P (2018) A N, P, C, and water flows metabolism study in a peri-urban territory in France: the case-study of the Saclay plateau. Resour Conserv Recycl 137:200-213. https://doi.org/10.1016/j.resconrec.2018.06.007

Wendland F, Bergmann S, Eisele M, Gömann H, Herrmann F, Kreins P, Kunkel R (2020) Model-Based analysis of nitrate concentration in the leachate-the North Rhine-Westfalia case study. Ger Water (Switz) 12(2):550

Wironen MB, Bennett EM, Erickson JD (2018) Phosphorus flows and legacy accumulation in an animal-dominated agricultural region from 1925 to 2012. Glob Environ Chang 50:88-99. https://doi.org/10.1016/j.gloenvcha. 2018.02.017

Zhang J, She Q, Chang VW, Tang CY, Webster RD (2014) Mining nutrients (N, K, P) from urban source-separated urine by forward osmosis dewatering. Environ Sci Technol 48(6):3386-3394

Publisher's Note Springer Nature remains neutral with regard to jurisdictional claims in published maps and institutional affiliations. 